\title{
Proteomic approach: Identification of Nephotettix virescens vector protein transmitting the tungro virus in rice
}

\author{
WASIS SENOAJI ${ }^{1,2}$, BAMBANG TRI RAHARDJO ${ }^{1}$, HAGUS TARNO ${ }^{1, \bullet}$ \\ ${ }^{1}$ Program of Postgraduate, Faculty of Agriculture, Universitas Brawijaya. Jl. Veteran, Malang 65145, East Java, Indonesia. \\ Tel. +62-0341-575843, fax. +62-0341-560011, ^email: h_gustarno@ub.ac.id \\ ${ }^{2}$ Tungro Disease Research Station. Sidenreng Rappang 91651, South Sulawesi, Indonesia.
}

Manuscript received: 23 March 2021. Revision accepted: 21 April 2021.

\begin{abstract}
Senoaji W, Rahardjo BT, Tarno H. 2021. Proteomic approach: Identification of Nephotettix virescens vector protein transmitting the tungro virus in rice. Biodiversitas 22: 2750-2755. As a vector of tungro virus, Nephotettix virescens is one primary pest in rice cultivars. Associated Rice Tungro Spherical Virus provides a helper component for Rice Tungro Bacilliform Virus acquisition produced the severe symptoms in rice. The vector proteins encoded by the virus become a poorly understood transmission of plant viruses, particularly in semi-persistent mechanisms. It is essential to develop new molecules to interrupt the transmission mechanism of plant viruses by insect vectors. This study aimed to detect the helper proteins in vectors with proteomics. Protein separation was performed using SDS-PAGE, and then was identified by the Liquid Chromatography-Mass Spectrometry (LC-MS/MS) to find the candidate proteins. The result showed that actin was identified in $N$. virescens as responsible protein that related to transmitting tungro viruses into the plant.
\end{abstract}

Keywords: Nephotettix virescens, protein, tungro, SDS-PAGE, MS/MS, actin

\section{INTRODUCTION}

Nephotettix virescens is one primary pest in rice cultivar because it is the tungro virus vector (Rice tungro virus, RTV) (Khan and Saxena 1985). RTV is an interaction of two different viruses between Rice tungro spherical virus (RTSV) and rice tungro bacilliform virus (RTBV), which are transmitted simultaneously or separately by the vector from plants infected with both virus particles (Hibino et al. 1979). The presence of RTSV in the vector body provides a helper component for RTBV acquisition, which is transmitted semi-persistently (Hibino 1996).

The hypothesis that the helper components form a "molecular bridge" can be reciprocal between vector and viruses (Froissart et al. 2002). While studies have shown that the protein encoded by the virus will support the development of new molecules to interrupt the transmission mechanism of plant viruses by vector insects (Fereres and Raccah 2015), non-structural proteins encoded by viral particles mediate virus-vector binding factor. However, the identity and function of helper proteins are also unknown (Ng and Zhou 2015).

A possible approach to detect the presence of helper proteins in $N$. virescens vector is the molecular approach with proteomics. Proteomics can describe an organism's protein identity (Pennington et al. 1997). A tool of tandem mass spectrometry (MS/MS) spectra generated the amino acid sequence and predicted to classify proteins by their similarity to current database entries (Liska and Shevchenko 2003). The sophisticated separation and prefractionation techniques have been developed to extend coverage, enhanced dynamic range and sensitivity (Zhang et al. 2014), mass spectrometry-based proteomics being the primary technique for large-scale protein characterization due to the complexity of proteomes. Protein expression on the interaction of vector and plant virus has been a comprehensive study. The helper component proteinase (HC-pro) of potyvirus in turnip mosaic virus was known to be involved in the formation of polyproteins, transmission, and suppression of antiviral RNA (Guo et al. 2011). Cuticular protein (CPR1) is used by the rice stripe virus to promote movement, replication, and continuity in the hemolymph of Laodelphax striatellus, even contributing to persistent transmission (Liu et al. 2015). The role of cuticular structures in the Aphid Acyrthosiphon pisum reveals candidate receptors against plant viruses at the stylet's tip (Deshoux et al. 2020). As described previously, protein was identified in several vector insects based on previous studies but till now, protein of $N$. virescens has not been unknown. So, protein identification is needed to investigate the tungro transmission activity by $N$. virescens.

\section{MATERIALS AND METHODS}

Nephotettix virescens vectors and tungro transmission test

Nephotettix virescens individuals were collected from an endemic area in Pasuruan region, East Java Province, Indonesia, in February 2020. The suspected plant was obtained from the field that indicated tungro symptoms. About 5-10 samples of the suspected plant were taken from a different location. Tungro transmission detected by Polymerase Chain Reaction (PCR) (Takahashi et al. 1993). PCR detection was targeted at RTBV gene because it has DNA structure more stable than RTSV. Total DNA 
extraction using Centhyl Trimethyl Ammonium Bromide (Doyle and Doyle 1990). Specific primer set was used on the gene of coat protein, i.e., DAF primer GGAATT CCGGCCCTCAAAAACCTAGAAG and DAR primer GGGGGTACCCCCCTCCGATTTCCCATGTATG. Product amplification targeted at $1400 \mathrm{bp}$. PCR reaction procedure was conducted according to Ladja et al. (2016). After it was confirmed as tungro symptoms, a direct transmission method was applied to maintain new infectious plants (inoculum sources). Tungro transmission test was applied to $180 \mathrm{~N}$. virescens adults. They were collected from the field by using a sweep-net, and then put in a portable insect cage unit. They were counted and transferred by using aspirator into two other cages containing infected and healthy plants. Finally, they were brought to the laboratory. A step of acquisition feeding on infected plants was done for $2 \times 24$ hours. Afterward, individuals were transferred to ten days old of seedling. Ciherang as a susceptible cultivar was chosen as the seedling. In the transmission test, inoculation feeding was conducted for $2 \times 24$ hours. It was done by one individual for one seedling. After the inoculation feeding step finished, every individual was collected and put into a microtube containing absolute ethyl-alcohol (ethanol 99\%), and then stored in the freezer at $-80^{\circ} \mathrm{C}$. The symptom of tungro transmission for the seedling test was done at 1, 2, 3, and 4 weeks after inoculation feeding - assessment of symptoms type based on evaluation standard (IRRI 2013). Symptoms were grouped into non-symptom, mild symptoms, and severe symptoms (Table 1). Healthy plants were used as control.

\section{Protein extraction}

Protein extraction was based on the symptoms that appeared on the tested plants. Twenty individuals for each group were weighed (ca. 50-100 mg), then extracted using the ReadyPrep ${ }^{\mathrm{TM}}$ Protein Extraction Kit (Bio-RAD). The extraction procedure followed the manufacturing protocol.

\section{Separation protein by SDS-PAGE}

Sodium dodecyl sulfate-polyacrylamide gel electrophoresis (SDS-PAGE) was used to separate proteins based on molecular weight (MW) with Laemmli buffer (Laemmli 1970). Samples were separated using SDSPAGE to obtain major protein. Usually, there are various limitations to 2-dimensional electrophoresis, including the difficulty of separating largest or smallest proteins and acidic or basic proteins (Hattori et al. 2015). The total protein samples were separated using 12\% SDS-PAGE. The sample's buffer solution contained acrylamide, $0.25 \mathrm{M}$ Tris- $\mathrm{HCl}$ (pH 8.8), 10\% SDS, 10\% APS, and TEMED. The sample protein concentration was measured using a nanodrop spectrophotometer to determine the concentration ratio to be added to the buffer. RSB buffer ratio with sample was $3: 1$. The sample and RSB were mixed and then heated at $100^{\circ} \mathrm{C}$ for 10 minutes. The $10-20 \mu$ of buffered samples were inserted into the electrophoresis well (buffer $\mathrm{pH}$ 8.3). The electrophoresis process was run at 100 volts for 60 minutes. The resulting protein bands were stained with Coomassie Brillant Blue (CBB).
Table 1. Standard assessment of disease severity caused by tungro transmission

\begin{tabular}{cl}
\hline Score & \multicolumn{1}{c}{ Symptoms } \\
\hline 1 & Non-symptom \\
3 & $1-10 \%$ reduction in height; no change in leaf color \\
5 & $11-30 \%$ reduction in height; no change in leaf color \\
7 & $\begin{array}{l}31-50 \% \text { reduction in height; there is a change in the } \\
\text { color of the leaves to yellow or orange }\end{array}$ \\
9 & $\begin{array}{l}>50 \% \text { reduction in height; there is a change in the } \\
\text { color of the leaves to yellow or orange }\end{array}$ \\
\hline
\end{tabular}

\section{Protein identification by LC-MS/MS}

A liquid chromatography-mass spectrometry (LC-MS/ MS) tool was used to identify the targeted protein. The protein bands from SDS-PAGE were selected for the in-gel digestion step. The procedure was carried out manually, tape was cut vertically, and then the gel pieces were prepared into peptides and extracted. The preparation process included reduction, alkylation, digestion, and peptide extraction steps. The used enzyme was trypsin (cleaves C-terminal for Lys and Arg) with two maximum missed cleavage. The allowed modifications were acetyl for N-terminal, oxidation for amino acid Methylthio, and carbamidomethyl for amino acid Cys.

\section{Data analysis}

MASCOT

search engine software (http://www.matrixscience.com/) was used to identify proteins from the LC-MS/MS output raw data. Validation of the peptide sequence was done using a probability MW search (Mowse) score. Protein identity can be confirmed if the Mowse score or Mascot score were $>54$ and $\geq 2$ unique peptides (Li et al. 2007; Mishra et al. 2016).

\section{RESULTS AND DISCUSSION}

\section{Tungro transmission}

The presence of $N$. virescens has been confirmed by PCR (Figure 1). The tested plants showed several types of transmission symptoms (highly severe, severe, and mild) compared to control (Figure 2). Result showed that vector $N$. virescens could transfer both RTSV and RTBV particles, particularly on seedlings showing severe symptoms.

\section{Characterized proteins of vectors Nephotettix virescens}

Qualitative and quantitative protein comparisons were carried out against all the vector groups typical symptoms by visualizing the major protein (abundant protein) on the protein band. Only relatively abundant protein can be colored with CBB. Both estimated MW of 49 and $54 \mathrm{kDa}$ in the vector group of severe symptoms were selected as protein candidates to be identified (Figure 3). Candidates have unique characteristics that only appear in the vector group of severe symptoms, and the quantity visually shows as thick and consistent at the second replication. 


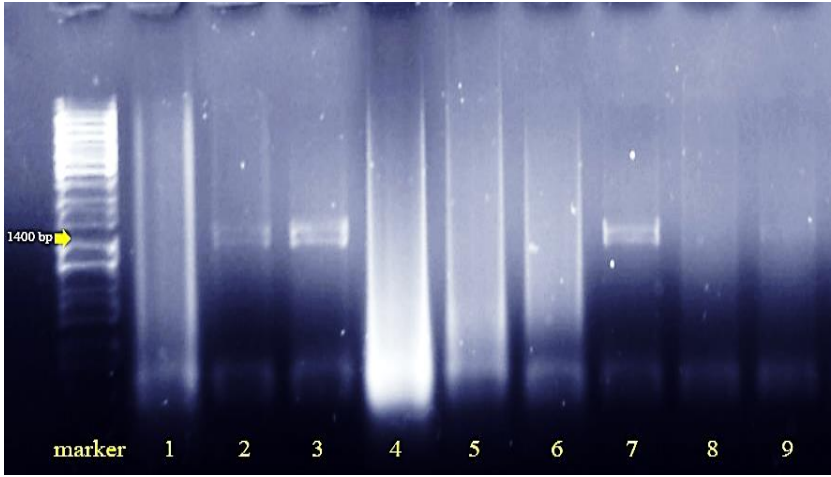

Figure 1. Results of detection tungro transmission based on RTBV occurrence in some suspected plants from the field by PCR. Sample no. 2, 3, and 7 showed infected plants by tungro disease
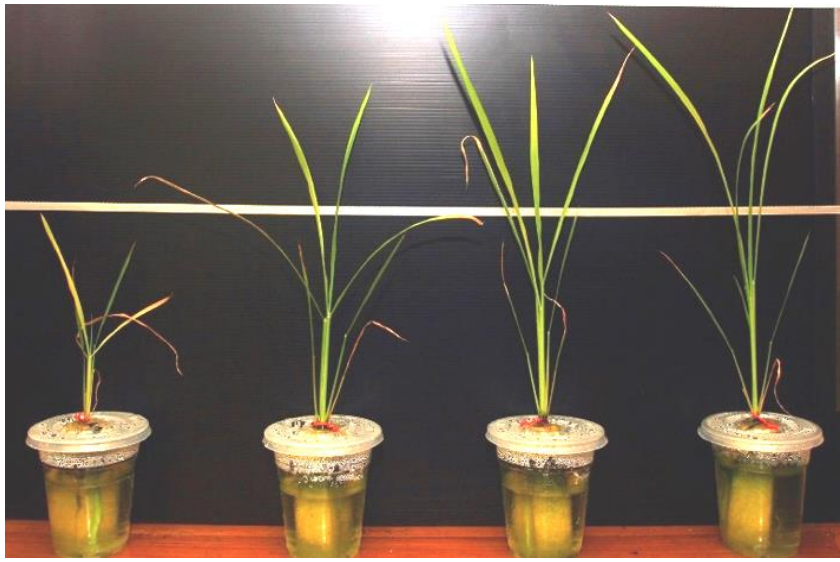

Figure 2. Assessment of tungro symptom types based on evaluation standard (IRRI 2013) on seedling test after 14 days after inoculation feeding. From left to right, symptoms visually showed highly severe, severe, mild, and non-symptoms (control).

\section{Protein identification by LC-MS/MS}

Identifying non-redundant (nr) peptide sequences in the UniProt database showed that the protein derived from vector insects was homologous to $N$. cincticeps (www.uniprot.org/taxonomy/94400), and shown in Table 2.
The SDS-PAGE analysis showed the same protein in MW of 49 and $54 \mathrm{kDa}$, namely, actin-2 or the protein group (member of protein family) actin. It showed that MS has a high level of sensitivity and accuracy. MS was an effort to verify the expected identity.

Target protein in this proteomic study has been identified. Identity obtained has more detailed derivative information on a database. It can be used or developed in subsequent studies, especially the interaction between vectors and tungro viruses. In this study, actin was first identified in the $N$. virescens, supposed to be involved in the interaction with the tungro virus which showed more severe infectious symptoms (> 30\% stunting and yellowing leaves).

\section{Discussion}

In the SDS-PAGE analysis, both BM estimates showed the same protein. In gel-based proteomic, gel staining is proportional to the total protein content of each gel band. It was not possible to characterize quantitative and qualitative information in more than one protein. It is a problem in most MS/MS identification due to the limited resolution of separation with SDS-PAGE (Campostrini et al. 2005). However, MS-based proteomics has been used primarily to identify, characterize, and quantify proteins. The accurate results have increased the use and confidence in molecular biology studies (Bensimon et al. 2012).

Identification method in this study uses a bottom-up strategy (Kellie et al. 2010). In the workflow, the protein is cut into smaller peptide fragments using an enzyme (trypsin), and then the peptide is analyzed by MS. Protein identification was based on two substances. First, the observed peptide mass's suitability with the prediction of protein values from the protein sequence database (Peptidemass fingerprinting, PMF). Second, the peptide sequence's suitability (conclusions from the MS/MS spectrum fragmentation) to the amino acid fragmentation of the protein sequence from the database (database searching). Protein identification can be determined at different levels of precision, depending on the analysis's objectives and success in identifying unique peptides (Szabo and Janaky 2015).

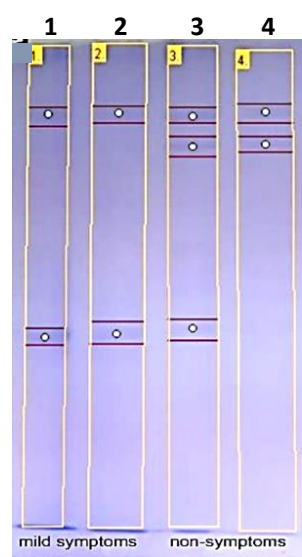

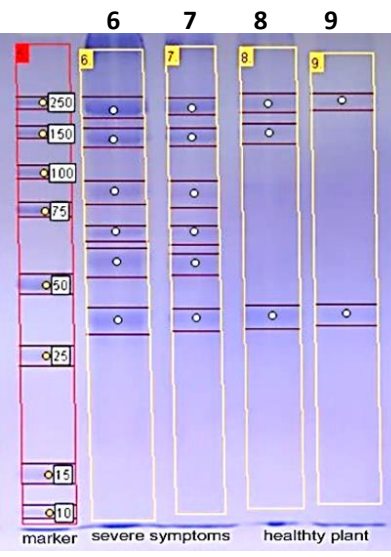

A

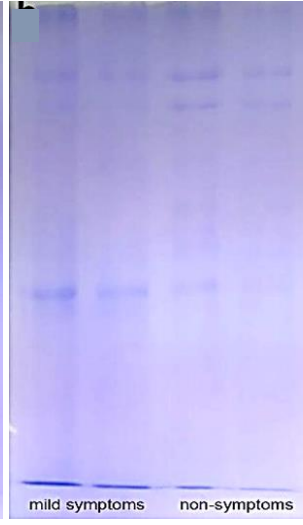

marker

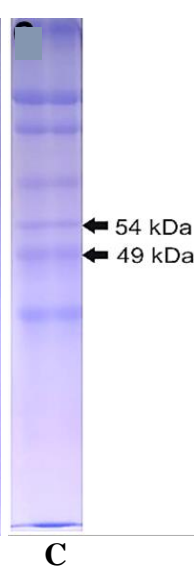

C

Figure 3. The protein band patterns of the Nephotettix virescens based on the tungro symptoms. A. Analyzed the protein band patterns based on major proteins that emerged. column 1-2: mild symptoms; column 3-4: non-symptom; column 5: ladder; column 6-7: severe symptoms; column 8-9: vectors treated to healthy plant; 1: candidate $54 \mathrm{kDa}$; 2 : candidate $49 \mathrm{kDa}$. B The major protein emerged, C. Protein band pattern of MW49 and $54 \mathrm{kDa}$ 
The facts related to actin proteins and actin-binding proteins (ABPs) have been extensively studied. In cells, actin has various functions (multi-function) from regulating gene expression to maintaining genome integrity. Actin is also called the cytoskeleton or cell skeleton (Mostowy and Shenoy 2015). Actin and ABPs are present in the cytoplasm and nucleus. ABPs regulate actin metabolism in response to various intra and extracellular signals (cell signaling), and where the presence of actin forms as free monomers is called G-actin and as part of microfilaments is called F-actin, both of which function in cell motility and contraction in cell division (Furukawa and Fechheimer, 1997), so circulating actin in the nucleus is a mechanism to maintain cell homeostasis (Davidson and Cadot 2020). There are three actin groups in eukaryotes based on their protein variants (isoforms), namely alpha, beta, and gamma. Alpha-actin occurs in muscle tissue, beta-actin and gamma-actin are often together as components of the cytoskeleton and mediators of internal cell motility (Kelber and Klemke 2011). While actin production is also the key to the process of infection by several pathogenic microorganisms (Kyheröinen and Vartiainen, 2020), it has recently been discovered that actin also plays a role in controlling gene expression and mutations cause some diseases in the alleles of genes that regulate actin production or the proteins associated with them.

The interaction of both actin and ABPs in insect vectors has been studied with several plant viruses. Myzus persicae vector is a subtropical climate plant pest. Receptor for activated C kinase (Rack-1), Glyceraldehyde-3-phosphate dehydrogenase (GAPDH3), and actin in the membrane complex binding Beet western yellows virus (BWYV) particles to facilitate transcytosis in the vector body. BWYV is a circular-persistent viral particle, bound by (Rack-1), (GAPDH3), and actin via micropinocytosis and polarized transport across epithelial cells using the cytoskeleton element pathway. However, the actual receptor for BWYV has not been identified (Seddas et al. 2004).

The cytoskeleton is a critical component of the intracellular transport route for the movement of plant viruses. Chen et al (2015) studied the non-structural protein interaction of the Rice Dwarf Virus (RDV) in its vectors Nephotettix cincticeps and Recilia dorsalis, which are sucking pests in rice plants. Protein responses revealed that microtubules and actin cytoskeleton in the vector supported the virus's movement across cell surface protrusions. The interaction of virus and insect actin can determine the specific insect vector. RDV and their vector relationship is a persistent transmission mechanism for rice plants (Chen et al. 2011). However, vector proteins with plant viruses that are non-persistent or semi-persistent are still poorly understood or studied.

Transmission of RTBV and RTSV viruses are a semipersistent mechanism by $N$. virescens vector studied in this study. The transmission test was carried out to provide a vector opportunity to acquisition feeding $2 \times 24$ hours from infected plants, then transferred to a healthy plant for $2 \times$ 24 hours. The results showed symptoms to transmit both viruses, causing severe symptoms ( $\geq 30 \%$ stunting and yellowing leaves). This treatment has implications for responding to more actin in the vector body during the transmission mechanism than the vector group with mild symptoms, non-symptoms, or vectors in healthy plants.

Table 2. The results of LC-MS/MS identification with the Mascot algorithm using the Basic local alignment search tool on the UniProt database against the estimated MW of 49 and $54 \mathrm{kDa}$ in the vector group severe symptoms.

\begin{tabular}{|c|c|c|}
\hline \multirow{2}{*}{ Protein characteristics } & \multicolumn{2}{|r|}{ Sample } \\
\hline & $49 \mathrm{kDa}^{1}$ & $54 \mathrm{kDa}^{1}$ \\
\hline Accession no. (gi IDs) ${ }^{2}$ & A0A125RA11 & A0A125RA11 \\
\hline Protein $(\mathrm{ID})^{3}$ & Actin 2 & Actin 2 \\
\hline Species $(\text { Taxonomy })^{4}$ & Nephotettix cincticeps & Nephotettix cincticeps \\
\hline Protein domain ${ }^{5}$ & actin & actin \\
\hline Mowse score ${ }^{6}$ & 84 & 414 \\
\hline Unique peptides $^{7}$ & 2 & 7 \\
\hline Sequence coverage $(\%)^{8}$ & 5 & 23 \\
\hline Predicted mass) (kDa)/PI ${ }^{9}$ & $42.081 / 5.29$ & $42.081 / 5.29$ \\
\hline A sequence of matched peptides) ${ }^{10}$ & AVFPSIVGRPR; GYSFTTTAER & $\begin{array}{l}\text { AVFPSIVGRPR; VAPEEHPILLTEAPLNPK; } \\
\text { DLTDYLMK; GYSFTTTAER; } \\
\text { SYELPDGQVITIGNER; EITALAPSTIK; } \\
\text { QEYDESGPGIVHR }\end{array}$ \\
\hline
\end{tabular}

Note: ${ }^{1}$ estimation of MW candidate protein on SDS-PAGE; ${ }^{2} \mathrm{ID}$ number on UniProt database; ${ }^{3}$ protein sample identity match to the UniProt database; ${ }^{4}$ homologous species; ${ }^{5}$ structural and functional unit of protein according to Pfam version 33.1 (http://pfam.xfam.org/); ${ }^{6}$ Mascot's probability score $>54$ indicates identity $(p<0.05)$, a higher score indicates the accuracy of the identity; ${ }^{7}$ the number of amino acids in a specific protein sequence found in the sequenced peptide in the MS/MS; ${ }^{8}$ The percentage coverage of the sample amino acid sequence to the homologous sequence; ${ }^{9}$ Molecular weight and isoelectric point accuracy at a $\mathrm{pH}$ indeed; ${ }^{10}$ Amino acid sequence match to database $\geq 2$ indicates protein identity. 
There are two hypotheses for this study. First, upregulated actin occurs in the tissue of the stylet sheath because RTSV and RTBV in the vector body are limited in that area. Second, a genetic response specifically to both RTSV and RTBV virus particles interacts intensively with actin. Proteomic analysis of the salivary glands and saliva secreted (watery/gelling saliva) showed that actin and ABPs activity occurs in rice-sucking pests i.e. Nilaparvata lugens and Sogatella furcifera (Huang et al. 2018) but is not expressed on $N$. cincticeps (Hattori et al. 2015). However, their interactions with plant viruses can be different and specific, especially with the RTBV and RTSV particles being semi-persistent viruses, the actin expressed on the $N$. virescens vector in this study is homologous to $N$. cincticeps and exhibited the same function in vector body metabolism. Thus, future studies can be done to the specific interaction mechanism of actin and ABPs proteins against RTBV and RTSV.

Interestingly, three-dimensional (3D) structure of actin expression showed homology to that of $N$. cincticeps. This information could be a hope regarding the management of pests and diseases in rice plants. 3D structures can be used as a further study with a combination of methods with an in-silico approach (Mishra et al. 2021) to predict and find new molecules as candidate components to control tungro disease from an insect vector perspective.

In conclusion, actin in $N$. virescens vector interacts with RTSV and RTBV, which causes the tungro symptoms in rice. Actin interactions can be specific with upregulating, although the quantity is not known. Actin could be a protein candidate that be studied further to design biomarkers.

\section{ACKNOWLEDGEMENTS}

We thank the Indonesian Agency of Agricultural Research and Development, Ministry of Agriculture, for invaluable support and encouragement. In addition, we also thank Kasmi Jufri (Tungro Disease Research Station), Erintha Eka Wardani (Institut Biosains), and Irma Kresnawati (Indonesian Research Institute for Biotechnology and Bioindustry) for laboratory support.

\section{REFERENCES}

Bensimon A, Heck AJR, Aebersold R. 2012. Mass spectrometry-based proteomics and network biology. Ann Rev Biochem 81: 379-405. DOI: 10.1146/annurev-biochem-072909-100424.

Campostrini N, Areces LB, Rappsilber J, Pietrogrande MC, Dondi F, Pastorino, F, Ponzoni M, Righetti PG. 2005. Spot overlapping in twodimensional maps: A serious problem ignored for much too long. Proteomics 5 (9): 2385-2395. DOI: 10.1002/pmic.200401253.

Chen H, Chen Q, Omura T, Uehara-Ichiki T, Wei T. 2011. Sequential infection of rice dwarf virus in the internal organs of its insect vector after ingestion of virus. Virus Res 160 (1-2): 389-394. DOI: 10.1016/j.virusres.2011.04.028.

Chen Q, Wang H, Ren T, Xie L, Wei T. 2015. Interaction between nonstructural protein Pns10 of rice dwarf virus and cytoplasmic actin of leafhoppers is correlated with insect vector specificity. J Gen Virol 96 (4): 933-938. DOI: 10.1099/jgv.0.000022.

Davidson PM, Cadot B. 2020. Actin on and around the Nucleus. Trends Cell Biol 31 (3): 211-223. DOI: 10.1016/j.tcb.2020.11.009.
Deshoux M, Masson V, Arafah K, Voisin S, Guschinskaya N, Van Munster M, Cayrol, B, Webster CG, Rahbé Y, Blanc S, Bulet P, Uzest M. 2020. Cuticular structure proteomics in the pea aphid Acyrthosiphon pisum reveals new plant virus receptor candidates at the tip of maxillary stylets. J Proteome Res 19 (3): 1319-1337. DOI: 10.1021/acs.jproteome.9b00851.

Doyle JJ, Doyle JL. 1990. A rapid total DNA preparation procedure for fresh plant tissue. Focus 12 (1): 13-15.

Fereres A, Raccah B. 2015. Plant virus transmission by insects. In eLS 112. DOI: 10.1002/9780470015902.a0000760.pub3.

Froissart R, Michalakis Y, Blanc S. 2002. Helper component-trans complementation in the vector transmission of plant viruses. $\begin{array}{llll}\text { Phytopathology } & 92 & (6): & 576-579 .\end{array}$ 10.1094/PHYTO.2002.92.6.576.

Furukawa R, Fechheimer M. 1997. The structure, function, and assembly of actin filament bundles. Intl Rev Cytol 175: 29-90. DOI: 10.1016/s0074-7696(08)62125-7.

Guo B, Lin J, Ye K. 2011. Structure of the autocatalytic cysteine protease domain of potyvirus helper-component proteinase. J Biol Chem 286 (24): 21937-21943. DOI: 10.1074/jbc.M111.230706

Hattori M, Komatsu S, Noda H, Matsumoto Y. 2015. Proteome analysis of watery saliva secreted by green rice leafhopper, Nephotettix cincticeps. PLoS One 10 (4): e0123671. DOI: 10.1371/journal.pone.0123671.

Hibino H. 1996. Biology and epidemiology of rice viruses. Ann Rev Phytopathol 34: 249-274. DOI: 10.1146/annurev.phyto.34.1.249.

Hibino H, Saleh N, Roechan M. 1979. Transmission of two kinds of rice tungro-associated viruses by insect vectors. Phytopathology 69: 12661268. DOI:10.1094/PHYTO-69-1266.

Huang HJ, Lu JB, Li Q, Bao YY, Zhang CX. 2018. Combined transcriptomic/proteomic analysis of salivary gland and secreted saliva in three planthopper species. J Proteomics 172: 25-35. DOI: 10.1016/j.jprot.2017.11.003.

IRRI. 2013. Standard Evaluation System for Rice. International Rice Research Institute, Philippines. DOI: 10.1063/1.1522164.

Kelber JA, Klemke RL. 2011. The actin cytoskeleton. In: Nabi IR (ed.). Cellular Domains. Wiley-Blackwell, New York. DOI: 10.1002/9781118015759.ch12.

Kellie JF, Tran JC, Lee JE, Ahlf DR, Thomas HM, Ntai I, Catherman AD, Durbin KR, Zamdborg L, Vellaichamy A, Thomas PM, Kelleher NL. 2010. The emerging process of top-down mass spectrometry for protein analysis: Biomarkers, protein-therapeutics, and achieving high throughput. Mol BioSyst 6 (9): 1532-1539. DOI: 10.1039/c000896f

Khan ZR, Saxena RC. 1985. Behavior and biology of Nephotettix virescens (Homoptera: Cicadellidae) on tungro virus-infected rice plants: Epidemiology implications. Environ Entomol 14 (6): 297-304. DOI: 10.1093/ee/14.3.297

Kyheröinen S, Vartiainen MK. 2020. Nuclear actin dynamics in gene expression and genome organization. Seminars Cell Develop Biol 102: 105-112. DOI: $10.1016 /$ j.semcdb.2019.10.012

Ladja FT, Hidayat SH, Damayanti TA, Rauf A. 2016. Rice tungro virus detection on weeds using PCR techniques. Penelitian Pertanian Tanaman Pangan 35 (1): 39-44. DOI: 10.21082/jpptp.v35n1.2016.p39-44

Laemmli UK. 1970. Cleavage of structural proteins during the assembly of the head of bacteriophage T4. Nature 227 (5259): 680-685. DOI: 10.1038/227680a0.

Li AQ, Popova-Butler A, Dean DH, Denlinger DL. 2007. Proteomics of the flesh fly brain reveals an abundance of upregulated heat shock proteins during pupal diapause. J Insect Physiol 53 (4): 385-391. DOI: $10.1016 /$ j.jinsphys.2007.01.003

Liska AJ, Shevchenko A. 2003. Expanding the organismal scope of proteomics: Cross-species protein identification by mass spectrometry and its implications. Proteomics 3 (1): 19-28. DOI: 10.1002/pmic.200390004

Liu W, Gray S, Huo Y, Li L, Wei T, Wang X. 2015. Proteomic analysis of interaction between a plant virus and its vector insect reveals new functions of hemipteran cuticular protein. Mol Cell Proteomics 14 (8): 2229-2242. DOI: $10.1074 / \mathrm{mcp} . M 114.046763$

Mishra M, Saurabh S, Maurya R, Mudawal A, Parmar D, Singh PK. 2016. Proteome analysis of Bemisia tabaci suggests specific targets for RNAi-mediated control. J Proteomics 132: 93-102. DOI: 10.1016/j.jprot.2015.11.020

Mishra S, Wang W, de-Oliveira IP, Atapattu AJ, Xia SW, Grillo R, Lescano CH, Yang X. 2021. Interaction mechanism of plant-based nanoarchitectured materials with digestive enzymes of termites as 
target for pest control: Evidence from molecular docking simulation and in vitro studies. J Hazardous Mater 403: 123840. DOI 10.1016/j.jhazmat.2020.123840.

Mostowy S, Shenoy AR. 2015. The cytoskeleton in cell-autonomous immunity: Structural determinants of host defense. Nat Rev Immunol 15 (9): 559-573. DOI: 10.1038/nri3877.

Ng JCK, Zhou JS. 2015. Insect vector - plant virus interactions associated with perspectives and future challenges. Curr Opinion Virol 15: 48 55. DOI: 10.1016/j.coviro.2015.07.006.

Pennington SR, Wilkins MR, Hochstrasser DF, Dunn MJ. 1997. Proteome analysis: From protein characterization to biological function. Trends Cell Biol 7 (4): 168-173. DOI: 10.1016/S0962-8924(97)01033-7.

Seddas P, Boissinot S, Strub JM, Van Dorsselaer A, Van Regenmortel MHV, Pattus F. 2004. Rack-1, GAPDH3, and actin: Proteins of
Myzus persicae potentially involved in the transcytosis of beet western yellows virus particles in the aphid. Virology 325 (2): 399412. DOI: 10.1016/j.virol.2004.05.014.

Szabo Z, Janaky T. 2015. Challenges and developments in protein identification using mass spectrometry. Trends Anal Chem 69: 76-87. DOI: 10.1016/j.trac.2015.03.007.

Takahashi Y, Tiongco ER, Cabauatan PQ, Koganezawa H, Hibino H, Omura T. 1993. Detection of rice tungro Bacilliform virus by polymerase chain reaction for assessing mild infection of plants and viruliferous vector leafhoppers. Phytopathology 83 (6): 655. DOI: 10.1094/phyto-83-655.

Zhang Z, Wu S, Stenoien DL, Paša-Tolić L. 2014. High-throughput proteomics. Ann Rev Anal Chem 7: 427-454. DOI: 10.1146/annurevanchem-071213-020216. 